\title{
IZRADA MREŽE IZVOZNIH PUTOVA I UZGOJNIH STAZA U ŠUMAMA HRASTA LUŽNJAKA KAO MJERA UČINKOVITIJE NJEGE I UČIINKOVITIJEGA KORIŠTENJA ŠUMSKIH RESURSA
}

\author{
ESTABLISHMENT OF A NETWORK OF HAULAGE TRACKS \\ AND SILVICULTURAL TRAILS IN PEDUNCULATE OAK \\ FORESTS AS A WAY OF MORE EFFICIENT STAND TENDING \\ AND MORE EFFICIENT FOREST EXPLOITATION
}

Darko POSARIĆ, Stjepan NIKOLIĆ

\begin{abstract}
SAŽETAK
Osnivanje uzgojnih staza u svrhu jednostavnijega rada njege pomlatka i učinkovitije kontrole u Hrvatskoj, prvi je puta napravljeno 1977. godine u Šumariji Đurđenovac (Sabljak 1990) i Šumariji Cerna. Od tada se postupno proširilo kao prihvaćena tehnologija rada uglavnom u slavonskim podružnicama Hrvatskih šuma, dok je u ostalima slabo prihvaćeno. Hrvatske šume d.o.o. do danas nisu analizirale učinkovitost ove tehnologije, već je odluka o njezinu provođenju ili ne provođenju prepuštana Upravama šuma podružnicama, pa čak i šumarijama. Suština tehnologije odnosi se na formiranje pravilne mreže izvoznih putova okomitih na glavni put ili makadamsku cestu širine $3 \mathrm{~m}$ te okomito na njih uzgojnih staza širine $1,5 \mathrm{~m}$. Proizvodna površina između staza različitih je širina u pojedinim UŠP-ima, ali najčešće iznosi $5 \mathrm{~m}$. Mreža se formira u godini prvoga uzgojnog zahvata nakon dovršnoga sijeka (prije popunjavanja sadnicama ili njege pomlatka). Radnicima je rad sa staza jednostavniji i lakši, a posebice je učinkovita kontrola. S druge strane, pokosi se između 24 i 29 \% već pomlađene površine, što je osnovni argument protivnicima ove tehnologije. U ovome radu predlaže se iskušati i drukačije razmake i položaje uzgojnih staza. Izvozni putovi izrađuju se kad i uzgojne staze, a koriste se za izvoženje drvnoga materijala od vremena početka proreda pa do kraja ophodnje. Razmak osi izvoznih putova u odjelima dimenzija $750 \times 750 \mathrm{~m}$ je 37,5 m, čime se površina odjela podijeli na 20 jednakih dijelova. U odjelima drukčijih dimenzija razmak varira, najčešće između 40 i $50 \mathrm{~m}$, a povećanje razmaka umanjuje učinkovitost izvoženja drva s njih. Stoga bi pokusno svakako trebalo ispitati i drukčije razmake osi izvoznih putova, na prvome mjestu onaj od 25 metara. Budući da o ovoj problematici kod nas ima iznimno malo pisanih materijala, a tehnologija je u primjeni dugi niz godina, ovaj rad ima za cilj opisati postojeće stanje, navesti dobre i loše strane osnivanja mreže izvoznih putova i uzgojnih staza te pokrenuti raspravu s konačnim ciljem definiranja optimalnoga načina rada, a posebice njegova unificiranja i primjene u svim šumama hrasta lužnjaka u nas.
\end{abstract}

KLJUČNE RIJEČI: Hrast lužnjak, njega pomlatka, uzgojne staze, izvozni putovi, izvoženje drva.

* Darko Posarić, dipl. ing. šum. i Stjepan Nikolić, dipl. ing. šum., obojica stručni suradnici uzgajanja šuma u Hrvatskim šumama d. o.o., Upravi šuma Podružnici Vinkovci, adresa: Trg bana Josipa Šokčevića 20, 32100 Vinkovci, adrese el. pošte: darko.posaric@hrsume.hr i stjepan.nikolic@hrsume.hr. 


\section{UVOD}

\section{INTRODUCTION}

Iako se u gospodarenju nizinskim šumama hrasta lužnjaka u Hrvatskoj osnivanje mreže izvoznih putova i uzgojnih staza u sastojinama pomlatka provodi već četrdesetak godina, mišljenja oko toga još su uvijek podijeljena. U šumarskoj praksi također se ne postupa jedinstveno. Razlikuju se metode osnivanja i gustoća mreže, a negdje se mreža uzgojnih staza uopće ne izrađuje. Početak izrade uzgojnih staza u mladim sastojinama seže u 1977. godinu. Ideja je došla prilikom posjeta stručnjaka iz tadašnjega Šumsko-privrednog poduzeća „Slavonska šuma“ Francuskoj 1975. godine, gdje su sudionici ekskurzije vidjeli pokuse njege mladih sastojina sa staza. Pokusna primjena započela je već dvije godine nakon toga, najprije u šumarijama Đurđenovaci Cerna. Odbor za proizvodnju ŠPP „Slavonska šuma" preporučio je 1980. godine ovu metodu za širu primjenu na temelju provjere prvih rezultata. Na našičkome području metoda je zaživjela već u osamdesetima, a na vinkovačkome u devedesetima.Na temelju iskustava brojnih primjena tehnologija usvojena je kao službena. Razlog je bio taj što su prednosti značajno nadmašivale nedostatke.

Radovi potrebni za uzgajanje kvalitetnih šuma i pridobivanje drva iz njih mogu se napraviti na više načina, korištenjem različitih tehnologija, alata i strojeva. Za najbolji rezultat treba uzgajanje šuma i pridobivanje drva promatrati kao neodvojivu cjelinu u gospodarenju šumama, i to u svjetlu cijele ophodnje. Potrebno je odabrati strategiju gospodarenja uvažavajući prednosti i nedostatke svih poznatih radova i tehnologija, kao i korištenja ovih ili onih strojeva i alata da se postigne cilj gospodarenja uz što niže troškove. Izvozni putovi i uzgojne staze izrađuju se ponajprije iz organizacijskih razloga. Cilj osnivanja izvoznih putova je unaprijed odrediti trase izvoza radi što jednostavnijega i učinkovitijega izvoženja drvnoga materijala, ali i da samo na njih budu ograničena oštećenja tla pri budućem izvoženju drva, dok se ostatak sastojine nastoji sačuvati u što boljem, po mogućnosti u netaknutom stanju. Ako se tijekom izvoženja tlo na trasama putova značajnije ošteti, sanacija je relativno jednostavna i moguće ju je obaviti dozerom, bagerom ili traktorom sa specijaliziranim priključkom, dok to u sastojini bez putova nije jednostavno napraviti. Uzgojne staze izrađuju se s ciljem jednostavnijega, bržega, lakšega i učinkovitijega rada u njezi pomlatka i mladika ili pri popunjavanju sadnicama, kao i zbog lakše i učinkovitije kontrole rada svakoga pojedinog radnika. S obzirom da ova problematika prožima cjelokupni način gospodarenja tijekom cijele ophodnje, cilj rada je, uz opis postojećega stanja i navođenje prednosti i nedostataka osnivanja mreže, pokrenuti raspravu

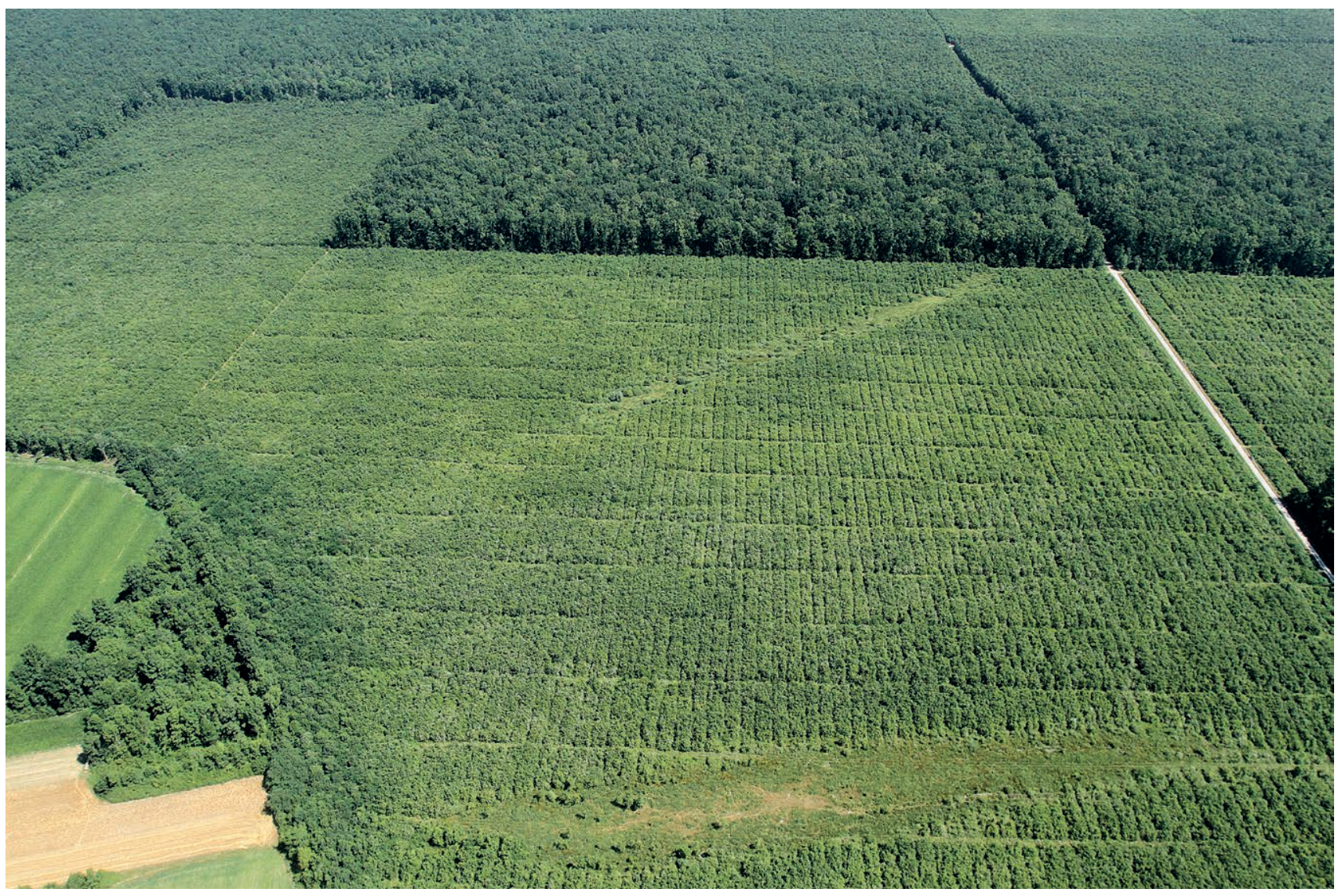

Slika 1. Formirana mreža izvoznih vlaka i uzgojnih staza u hrastovom pomlatku (Z. Tanocki)

Figure 1: Established network of haulage tracks and silvicultural trails in oak forest in sapling stage (Z. Tanocki) 

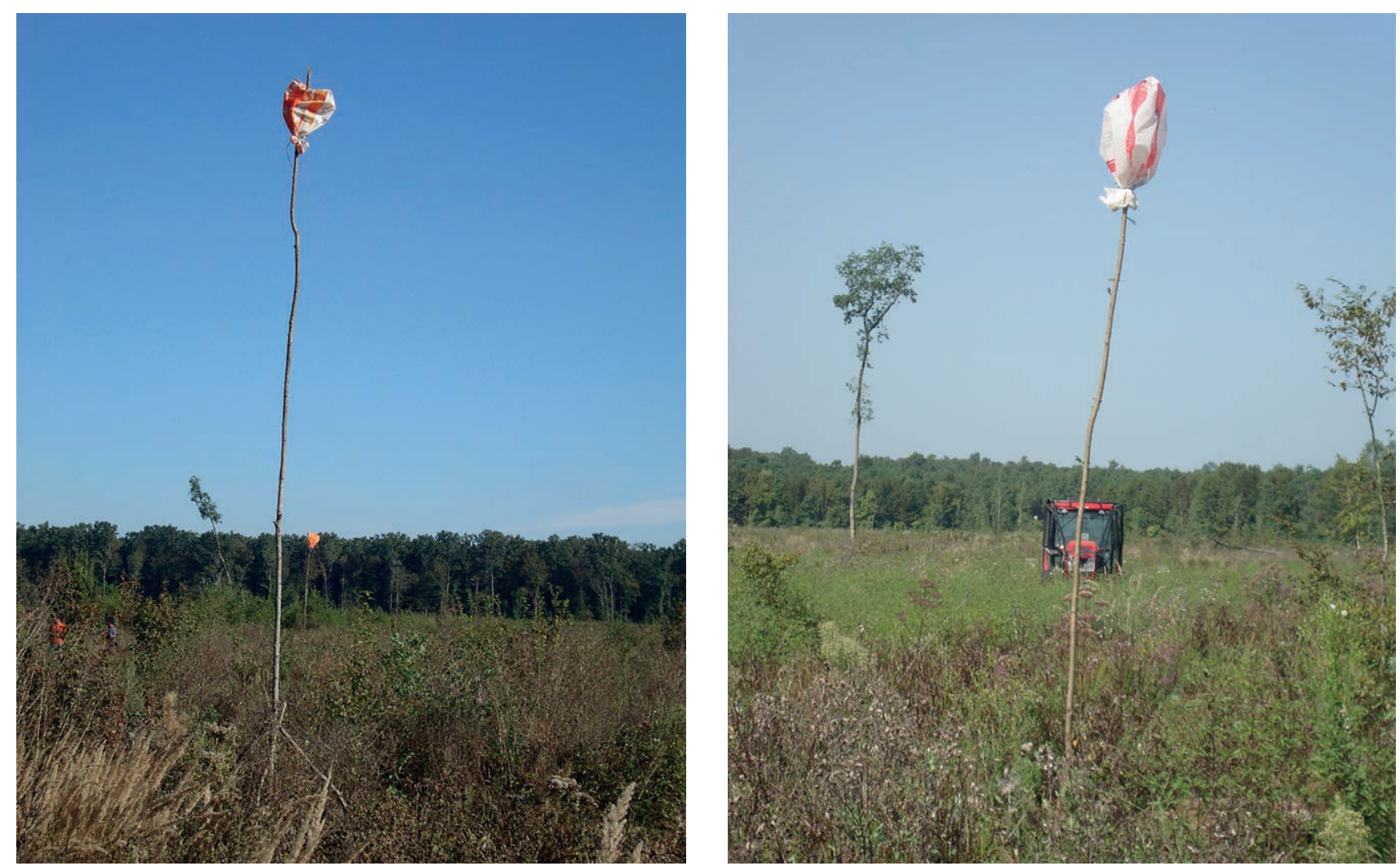

Slika 2. Izrada uzgojnih staza pomoću visokih trasirki (D. Posarić)

Figure 2: Creating of silvicultural trails using marking by long poles (D. Posarić)

i potaknuti znanstvena istraživanja koja bi trebala definirati optimalni način rada i omogućiti njegovo unificiranje i primjenu u sastojinama hrasta lužnjaka.

\section{NAČIN RADA \\ MODE OF OPERATION}

Osnivanje mreže izvoznih putova i uzgojnih staza: Mreža budućih izvoznih putova i uzgojnih staza osniva se nakon dovršnoga sijeka u mladoj sastojini neposredno prije provedbe prvoga uzgojnoga zahvata, bilo njege pomlatka, bilo popunjavanja dijelova pomladne površine sadnicama (do tri godine nakon dovršnoga sijeka). U pravilnim odjelima nizinskih šuma $(750 \times 750 \mathrm{~m})$ uobičajeno je da se izvozni putovi izrađuju u širini od $3 \mathrm{~m}$ na udaljenosti između osi od 37,5 m, a uvijek su položeni okomito na šumsku cestu (tvrdi put). Okomito na njih, a paralelno sa šumskom cestom izrađuju se uzgojne staze širine $1,5 \mathrm{~m}$ na udaljenosti između osi od $6,5 \mathrm{~m}$. Kad se posao dovrši, mreža izvoznih putova i uzgojnih staza omeđuje segmente obrasle površine dimenzija $34,5 \times 5$ metara (Posarić, 2007), što se može vidjeti na Slici 1. Širina sitnilice pri osnivanju i rotosjekača pri održavanju uzgojnih staza je oko 1,5 metar, što je ujedno i širina staze, a obrasle površine između staza široke su najčešće po 5 metara (npr. UŠP Našice, Osijek i Vinkovci), ali ima primjera da su široke 10 m ili šire (npr. UŠP Požega i Nova Gradiška).
Dvije uzgojne staze izrađuju se u dvostrukoj širini (3 m), jedna na $250 \mathrm{~m}$ i druga na $500 \mathrm{~m}$, one čine protupožarne putove. Razmak između izvoznih putova uvjetovan je dimenzijama odjela u nizinskim šumama. Pravilni odjeli, kako je već navedeno, dimenzija su $750 \times 750$ metara. Oni se pri doznaci i sječi podijele na 10 jednakih cjelina - sječnih linija širine $75 \mathrm{~m}$. Ta širina odgovara dvostrukoj visini dominantnih stabala i ne smije biti manja zbog obveznih međusobnih udaljenosti susjednih sjekačkih ekipa pri obaranju stabala. Doznaka i sječa rade se u tim zasebnim cjelinama, ali one su preširoke za privlačenje drva. Stoga je odlučeno sredinom svake postaviti još jedan izvozni pravac, čime se dobiva razmak osi izvoznih putova od 37,5 m. Širina putova od $3 \mathrm{~m}$ uvjetovana je širinom sitnilice i rotosjekača (oko 1,5 m), pa kad se spoje dva prohoda (otkosa) dobiva se širina od oko $3 \mathrm{~m}$, koja omogućava nesmetan prolazak traktora. Razmak između uzgojnih staza od 5 m određen je još 1979. operativnom uputom „Slavonske šume“ (Sabljak, 1990), jer su se razmaci od $30 \mathrm{~m}$ i $10 \mathrm{~m}$, koji su također pokusno korišteni, pokazali nedovoljnima za učinkovit rad. Zaključeno je da se u organizacijskome smislu pri širinama većim od 5 metara smanjuje učinkovitost rada, ali i kontrole, pa je ta širina tada odabrana kao ona koja će se operativno koristiti s ciljem da se njega napravi što lakše i jednostavnije, uz zadržavanje dovoljnih širina koje će omogućiti prirodan rast i razvoj većine biljaka. Što se tiče tehnologije izrade, 

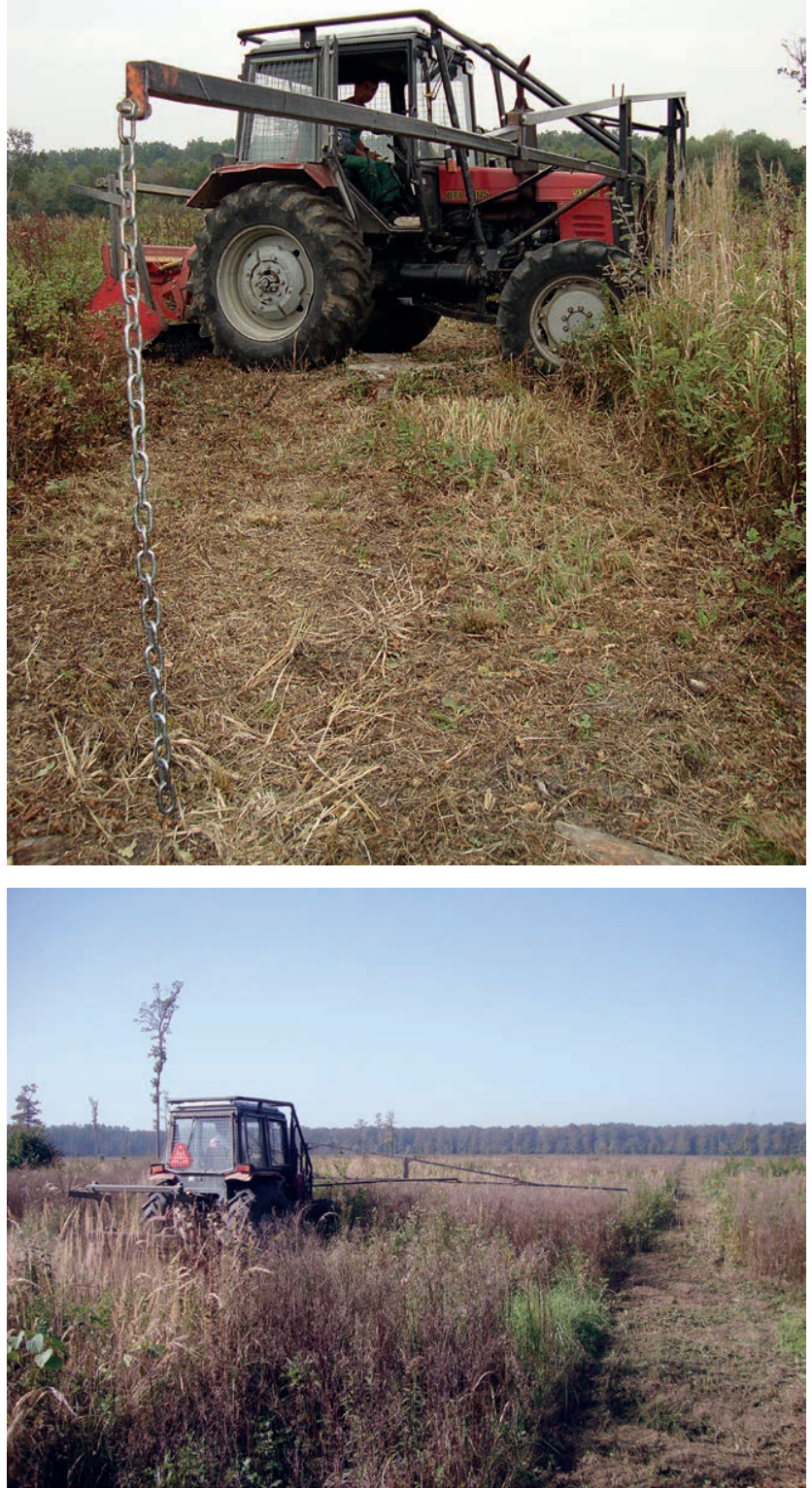

Slika 3. Izrada uzgojnih staza uz pomoć bočne poluge (D. Posarić)

Figure 3: Creating of silvicultural trails with the help of the sidebar (D. Posarić)

ona je tijekom vremena napredovala. U početku je s dviju nasuprotnih strana odjela najprije rađeno precizno razmjeravanje mjernom vrpcom $i$ iskolčavanje osi izvoznih putova. Potom bi čitavom dužinom odjela bile uravnate četiri vrlo visoke trasirke (tzv. mašale), a traktorist bi radio dogledajući poravnate trasirke (Slike 2.1 i 2.2). U povratku bi provukao drugi prohod uz prvi i tako bi izradio sve izvozne putove. Nakon toga na preostale dvije nasuprotne stranice odjela ponovilo bi se razmjeravanje i iskolčavanje, ovoga puta na razmacima od $6,5 \mathrm{~m}$ i nakon toga bi se sitnilicom izvukle uzgojne staze okomito na izvozne pravce, također uz praćenje uravnatih visokih trasirki dužinom odjela. $\mathrm{Na}$ ovaj način izvozni putovi i staze precizno su

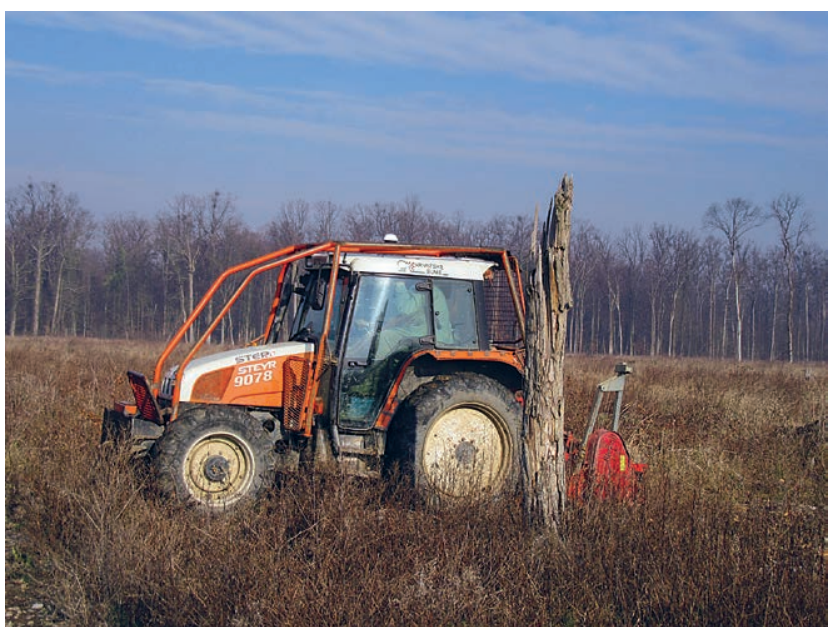

Slika 4. Izrada uzgojnih staza GPS navođenjem (D. Posarić)

Figure 4: Creating of silvicultural trails by GPS navigation (D. Posarić)

rađeni uz učinak nešto manji od 1 ha dnevno i uz rad 3 radnika dnevno. Godine 2006. revirnik Mario Blaževac osmislio je jednostavan način kojim se traktorist sam orijentira prema susjednoj stazi spajanjem na traktor bočne metalne poluge dužine $5 \mathrm{~m}$, na čijem je kraju visio lanac (Slika 3.1). Traktorist iz kabine vidi susjednu stazu i drži pravac na način da lanac pri radu visi točno na njezinu rubu (Slika 3.2). Tako je traktorist pomoću trasirki radio samo izvozne putove, a sve uzgojne staze je izrađivao uz pomoć bočne poluge, što je predstavljalo veliku uštedu radnikodana. Tehnologija GPS navigacije uvedena je 2015. godine u sve šumarije Uprave šuma podružnice Vinkovci (na po jedan traktor). Pokazalo se da se satelitskim navođenjem može vrlo precizno formirati mreža izvoznih putova i uzgojnih staza (Slika 4), ali također provoditi zaštitu od hrastove pepelnice i obavljati sve druge poslove koji su do tada zahtijevali trasiranu površinu. Nedostatak joj je veliko odstupanje pri nailasku na neporavnate kolotrage nastale

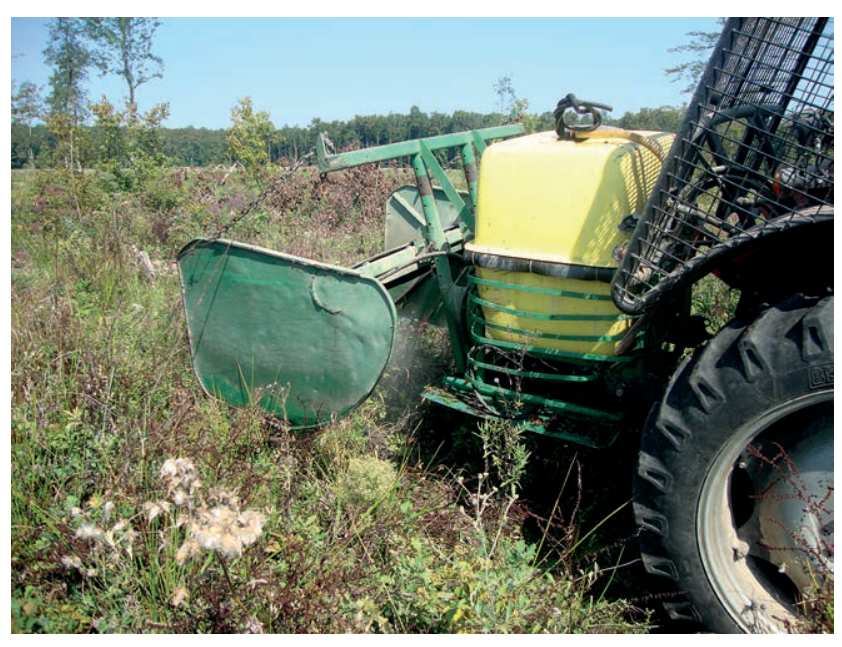

Slika 5. Izrada uzgojnih staza kemijskim tretmanom (D. Posarić)

Figure 5: Creating of silvicultural trails by chemical treatment (D. Posarić) 
tijekom izvoženja drva, jer prijemnik se u pravilu nalazi na krovu traktora, koji pri nailasku na prepreku ima najveći bočni otklon. Prelazak panjeva ne predstavlja toliko velik problem, jer je otklon u stranu vremenski kratak. Da bi se doskočilo ovome problemu prijemnik se može premjestiti na niže mjesto na traktoru, čime odstupanja postaju manja. Satelitskim navođenjem omogućen je precizan rad bez pomoćnih radnika. Treba napomenuti da se osim sitnilicom stazice mogu osnovati i kemijskim tretmanom, što je jeftinija opcija. U tome slučaju u vegetaciji kada će se raditi prvi zahvat njege, ali barem mjesec dana ranije, ili čak u vegetaciji koja joj prethodi traktorom sa specijaliziranim priključkom tretira se herbicidom samo širina staze (Slika 5). Nakon toga održavanje ne treba raditi dok god se razaznaje položaj staza (Slika 6), što je u pravilu dvije do tri godine, a tada održavanje napraviti rotosjekačem. U godini idućega zahvata njege iznova pokositi stazice rotosjekačem, odnjegovati površinu te opet iduće godine tretirati staze herbicidom. Na taj način ušteda je najveća, jer nema potrebe za svakogodišnjim održavanjem.

Njega sastojine s uzgojnih staza: Ako dvojica radnika njeguju isti segment sastojine rad započinju jedan preko puta drugoga sa susjednih staza i tijekom rada kreću se približno usporedno. Svaki radnik njeguje širinu od oko 2,5 $\mathrm{m}$, tj. do polovice segmenta dok ne završe, nakon čega nastavljaju rad na segmentu u produžetku. Ako radnik radi sam najprije njeguje jednu stranu, pa u povratku drugu, nakon čega prelazi na idući segment. Ovisno o gustoći sastojine u kojoj radi, dužini ruke i drške kosira radnik sa staze može dohvatiti oko 1 metar sa svake strane ili nešto više, a središnja 2,5 - 3 metra mora ući koji korak unutar segmenta i odnjegovati. No kretanje stazama znatno je ugodnije od neprestanoga probijanja kroz gustiš mladih sastojina. Poslovođa ili revirnik pri kontroli točno znaju koji je radnik što radio i ako dio posla nije dobro napravljen

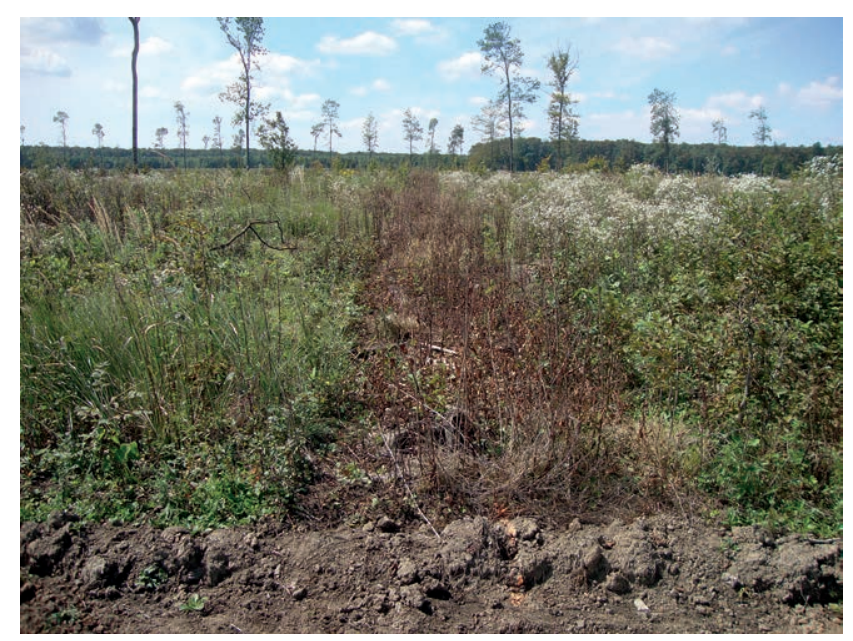

Slika 6. Uzgojna staza formirana kemijskim putem (D. Posarić) Figure 6: Silvicultural trail formed by chemical means (D. Posarić) radnike koji su lošije radili vraćaju da poprave. Radnici se ne mogu pravdati da je to napravio netko drugi, kao u skupnom radu širinom cijele površine, kad se u slučaju lošijega rada najčešće moraju vratiti svi, i oni koji su radili dobro i oni koji nisu, jer je teško utvrditi tko je pogriješio. U radu sa uzgojnih staza jasno je tko je pogriješio te se vrlo brzo uspostavlja ispravan način rada svih radnika. Poslovođa obavezno vodi svakodnevnu poimeničnu evidenciju radnika po segmentima, tako da je kontrola uvijek moguća.

Popunjavanje nedovoljno pomlađenih površina s uzgojnih staza: Ako se utvrdi da neke dijelove pomladne površine nakon dovršnoga sijeka treba popuniti, formiranje mreže izvoznih putova i uzgojnih staza može također pomoći u organizaciji toga posla. Nakon osnivanja mreža se kartira i pregleda se cijela površina. Oboje se čitavi segmenti ili njihovi dijelovi koje treba popuniti te izračuna ukupna površina, na temelju koje se određuje i ukupan broj sadnica (odredi se vrsta drveća i broj sadnica po hektaru za popunjavanje te pomnoži s ukupnom površinom). Poslovođa i radnici ne moraju lutati tražeći mjesta popunjavanja, jer sve je razvidno s karte. Sadnju treba provoditi u dogovorenim razmacima, a od staze se odmaknuti 0,5-1 m.

\section{PREDNOSTI I NEDOSTATCI ADVANTAGES AND DISADVANTAGES}

Objektivno uočeni nedostatci primjene mreže izvoznih putova i uzgojnih staza s razmacima $34,5 \times 5 \mathrm{~m}$ su sljedeći:

1) mreža izvoznih putova i uzgojnih staza međusobno udaljenih 5 m zauzima $29 \%$ prethodno pomlađene površine,

2) nakon osnutka mreža se mora održavati košnjom,

3) stabla uz izvozne putove i uzgojne staze često su oštećena od strojeva za održavanje,

4) stabla uz staze u prvim godinama mogu razviti nepravilnu krošnju, a uz izvozne putove ova opasnost postoji sve do dobi od tridesetak godina,

5) šumske površine ispresijecane pravilnom mrežom uzgojnih staza djeluju pomalo umjetno, poput šumskih kultura.

Ad 1) Činjenica je da se nakon ravnomjernoga unosa žira na pomladnu plohu 29 \% površine pri osnivanju mreže izvoznih putova i uzgojnih staza pokosi, čime se uništavaju i uspješno ponikle hrastove biljke. Time se dio biljaka u koje su uložena određena sredstva svjesno žrtvuje radi kasnijega jednostavnijega i učinkovitijega gospodarenja. No, raspored staza takav je da preostala obrasla površina osigurava dobru pokrovnost, a krošnjice postojećih stabalaca do 15. ili najkasnije 20. godine potpuno se spajaju tvoreći suvislo obraslu cjelinu (Slika 7).

Ad 2) Mreža izvoznih putova i uzgojnih staza osniva se nakon dovršnoga sijeka, u godini kad je potrebno raditi 


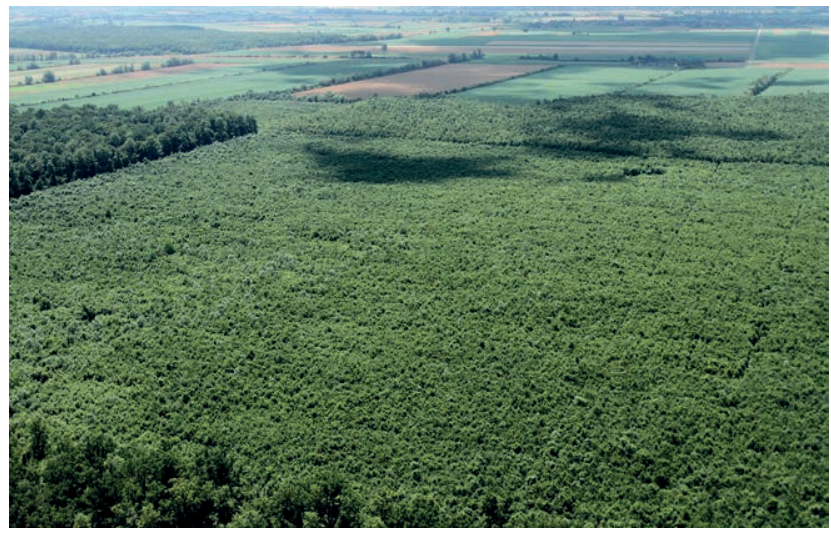

Slika 7. Položaj izvoznih vlaka i uzgojnih staza u hrastovom mladiku jedva se nazire (Z. Tanocki)

Figure 7: The location of haulage tracks and silvicultural trails in oak young growth is barely noticeable (Z. Tanocki)

prvu njegu pomlatka. Ako se radi samo strojno barem dvije godine nakon toga održavanje se mora raditi svake godine, a dalje prema potrebi, najčešće svake druge godine. Ako se osnivanje radi tretiranjem staza herbicidom, tada one ostaju vidljive dvije do čak tri godine. U godini iduće ručne njege održavanje rotosjekačem obvezno se napravi prije zahvata. Unatoč tomu, ukupni troškovi pri nekoliko strojnih održavanja u odnosu na samo ručni rad (bez staza) u godini potrebe su niži, jer cijena izrade i održavanja staza strojno značajno je niža od cijene klasičnoga ručnoga zahvata. Pri održavanju staza tretmanom herbicidom troškovi su još niži, jer je ovakav način jeftiniji od strojnoga rada, a učestalost održavanja manja.

Ad 3) Stabalca neposredno uz uzgojne staze, a posebice uz izvozne putove često su dijelom nagažena ili oguljena od traktora ili priključka. Većina tih vidljivo oštećenih stabala biva kasnijim prorednim zahvatima izlučena iz sastojine, a koliki su stvarni razmjeri ovih šteta tijekom života i rasta sastojine te koliki je eventualni iznos gubitka zbog smanjene vrijednosti drvnih sortimenata nije poznato.

Ad 4) Stabla rastu otklanjajući se prema svjetlu. Budući da relativno često održavanje uzgojnih staza dovodi biljkama više svjetla s jedne strane, stabalca koja ostaju neposredno uz staze mogu biti nagnuta prema njima. Uz izvozne putove ovaj je problem još izraženiji, jer njihova širina je $3 \mathrm{~m}$ i u dobi najintenzivnijega rasta sastojine (okvirno između 15. i 20. godine života) stabla uz putove mogu razviti nepravilnu krošnju.

Ad 5) Postoje određeni prigovori da se izradom izvoznih putova i uzgojnih staza gubi dojam prirodnosti sastojina i da one počinju sličiti na umjetno podignute nasade (Slika 1). Bez obzira na takav dojam ostaje činjenica prirodnoga porijekla i nastanka šuma. Stazice se održavaju otprilike do 15. godine života sastojine, već nakon 20 . godine obrastu do te mjere da se jedva razaznaju (na Slici 7 stanje u stari- jemu mladiku). U mladim sastojinama dobi oko 30 godina položaj staza najčešće više nije vidljiv.

Prednosti osnivanja mreže izvoznih putova i uzgojnih staza $s$ razmacima $34,5 \times 5 \mathrm{~m}$ su:

1) bolja je preglednost, prohodnost i olakšan rad njege sastojina,

2) veći su učinci radnika u njegama i manja je mogućnost njihove ozljede,

3) na dijelovima površina gusto obraslim trnovitim ili agresivnim biljnim vrstama (crni trn, glogovi, kupina, divlja ruža, amorfa itd.) njega sa staza gotovo da je jedini način da se cijela površina odsjeka ravnomjerno i kvalitetno odnjeguje,

4) jednostavna je i pregledna kontrola, točno se zna koji radnik je radio koji segment,

5) u slučaju velikoga broja i bujnoga rasta nepoželjnih vrsta presječeni dijelovi mogu se odlagati na staze,

6) jednostavniji je obračun učinka pojedinog radnika,

7) u slučaju slabijega uspjeha obnove, površine za popunjavanje su manje, jednostavna je obilježba i kartiranje zona koje treba popuniti

8) rad je organizacijski kudikamo lakši,

9) potrebno je manje ljudskoga rada u njegama, što je u nestašici radne snage vrlo značajno,

10) rad je u sadašnjim uvjetima jeftiniji.

Ad 1) Osnovna prednost izrade uzgojnih staza je značajno lakši rad njege u stadiju pomlatka i mladika. Radnici se kreću stazama i sasijecaju nepoželjne vrste od staze prema unutra, svaki radnik sa svoje strane radeći polovicu širine segmenta, ili samo jedan radnik najprije s jedne, a poslije s druge strane. Rad je pregledniji, a kretanje po pokošenim stazama jednostavnije i ugodnije, pa se radnici manje umaraju.

Ad 2) Budući da se radnici ne moraju svo vrijeme probijati kroz gustiš već dio vremena rade sa staze, mogućnost ozljede je manja, a radnici mogu odnjegovati nešto više površine.

Ad 3) Dijelovi površine obrasli kupinom ili drugim trnovitim biljkama mogu biti djelomično neprohodni radnicima, pa hrastove biljke unutar njih propadnu. Slično je u slučaju širenja agresivnih vrsta poput amorfe, koja vrlo brzo naraste i sklopi krošnje iznad hrasta. Staze otvore dio svjetla hrastu, pa barem rubno uz njih hrast ne propadne između dvaju zahvata njege. Osim toga, sa staza je moguće puno kvalitetnije odnjegovati hrast i u ovakvim nepovoljnim uvjetima, jer radnici uspiju zaći potrebnih oko $1,5 \mathrm{~m} \mathrm{u}$ dubinu segmenta i preostali $1 \mathrm{~m}$ dohvate kosirom.

Ad 4) Pri kontroli kvalitete rada poslovođa, revirnik, upravitelj ili stručni suradnik uopće se ne moraju probijati kroz trnovite mlade šume već sa staze točno vide svaki detalj 
odnjegovane površine. Zna se poimence tko je radio u kojemu segmentu i bilo kada ga se može vratiti da nešto popravi (svakako bilo kakvu uočenu pogrešku treba nastojati popraviti istoga dana).

Ad 5) Ponekad drvenaste vrste koje ugrožavaju hrast (grab, klen, brijest, lipa, topola, vrba, jasen itd.) mogu biti vrlo bujnoga rasta. Zbog toga odsječene dijelove stabala nije uvijek moguće rasporediti pokraj hrastovih biljaka jer bi ih ti bujni presječeni dijelovi savili i prekrili. U tome slučaju radnici veći dio odsječenoga materijala odlažu na staze (Slika 8). Iduće godine pri održavanju staza rotosjekač usitni te, do tada potpuno isušene biljne dijelove.

Ad 6) Za obračun učinka samo treba zbrojiti segmente koje je pojedini radnik napravio u obračunskome razdoblju i pomnožiti ih s površinom pojedinačnoga segmenta, koja je $172,5 \mathrm{~m}^{2}\left(34,5 \mathrm{~m} \times 5 \mathrm{~m}=172,5 \mathrm{~m}^{2}\right)$.

Ad 7) U zonama slabijega uspjeha obnove površina popunjavanja je manja za površinu izvoznih putova i staza. Obilježba i kartiranje radi se po segmentima, zone popunjavanja na taj je način vrlo jednostavno pronaći, kontrola rada uvijek je moguća poimenično po segmentima.

Ad 8) Iz svega do sada navedenoga razvidno je da je rad organizacijski značajno jednostavniji u svim fazama: planiranja, provedbe, kontrole i obračuna učinka radnika.

Ad 9) Budući da površina izvoznih putova i uzgojnih staza formirana na opisani način zauzima $29 \%$ ukupne površine odjela, jasno je da je za toliko manja i površina koju treba njegovati ručno. U nestašici radne snage to je vrlo značajna prednost.

Ad 10) Ukupni troškovi njega u odjelima s formiranom mrežom uzgojnih staza manji su nego u slučaju da staze nisu napravljene, što će biti prikazano u raspravi.

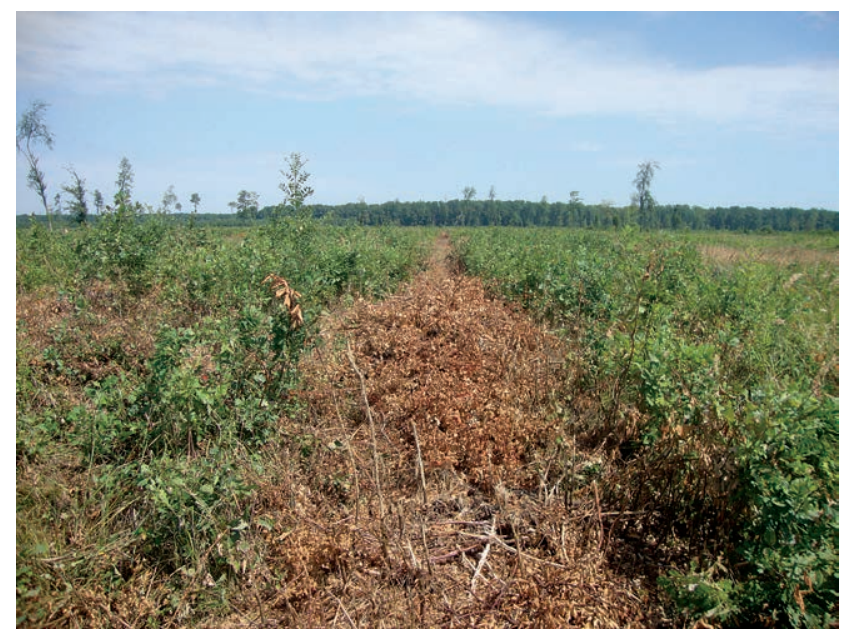

Slika 8. Sasječeni materijal u njezi odložen na uzgojnu stazu (D. Posarić)

Figure 8: Cut off material disposed along the silvicultural trail (D. Posarić)

\section{RASPRAVA DISCUSSION}

U raspravi ćemo pokušati odgovoriti na pitanja treba li formirati mrežu izvoznih putova i uzgojnih staza, ako da kada je najbolje vrijeme za to, koje bi bile preporučene širine putova i staza i njihovi međusobni razmaci te kojom tehnologijom provoditi rad. Na kraju ćemo izračunati cijene rada po hektaru za različite tehnologije rada i njihove kombinacije. Zasebno će se raspraviti opravdanost osnivanja budućih izvoznih putova i uzgojnih staza.

Način izrade izvoznih putova pitanje je cjelokupne organiziranosti šumarstva, a posebice načina rada na pridobivanju drva. Njihova širina i razmaci kasnije izravno utječu na odabir strojeva koji će izvoziti drvo, a što je opet povezano s nosivosti tla te vrstom i dimenzijama sortimenata koji će biti izvoženi iz šume na cestu. Brojni autori bavili su se problematikom izrade izvoznih putova u sastojinama. Slabak (1983) među prvima navodi da se prilikom uvođenja izvoženja drva forvarderima u nizinske šume Hrvatske pojavila potreba za izradom mreže traktorskih putova. Greulich i dr. (2004) iznose spoznaje da se površina gaženja tla pri neograničenome kretanju strojeva koji privlače drvo povećava za $25 \%$ u odnosu na njihovo ograničeno kretanje po mreži planski projektiranih putova. Autori koji su proučavali ovu problematiku slažu se da se na gaženje tla, osim nekim značajkama vozila, najviše može utjecati pripremom rada i drugim organizacijskim mjerama (Poršinsky 2005, Pandur i dr. 2014), od kojih je planska izrada izvoznih putova sigurno u samome vrhu. Brojna su nastojanja istraživača na globalnoj razini vezana uz smanjenje sabijanja šumskoga tla uslijed kretanja vozila za privlačenje i izvoženje drva (Allman i dr. 2015, Borchert i dr. 2015, Cambi i dr. 2016, Cudzik i dr. 2017, Labelle i dr. 2015, Poršinsky i dr. 2011, Solgi i dr. 2015, Solgi i dr. 2017). Zbog toga formiranje mreže izvoznih putova

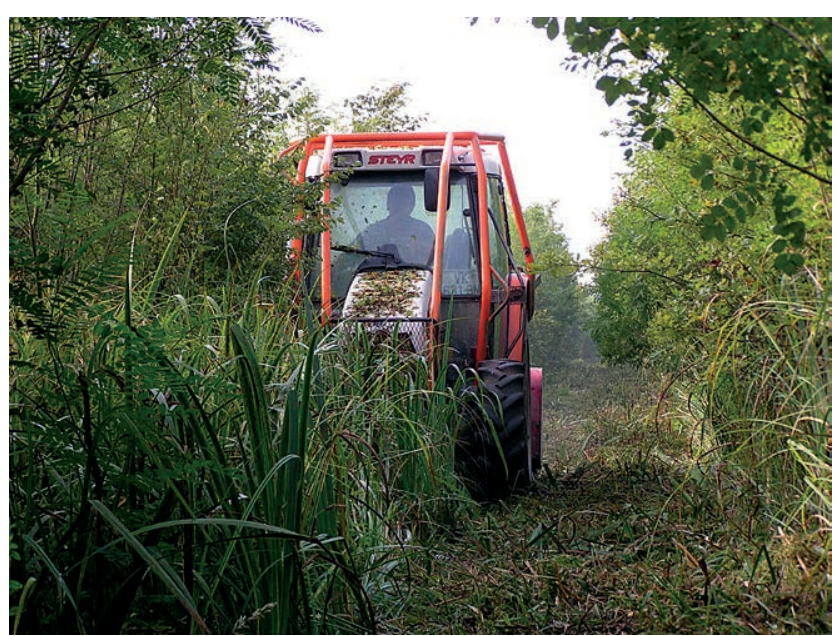

Slika 9. Održavanje izvoznih vlaka u stadiju mladika (D. Posarić) Figure 9: Maintaining haulage track by mowing in the stage of young growth (D. Posarić) 
smatramo korisnim i potrebnim. Po njima se drvo izvozi iz šume kontrolirano, uz najmanju štetu za sastojinu i uz najmanju površinu gaženja, dakle i najmanju štetu za tlo. K tome, u slučaju rada na slabo nosivoj podlozi i nastanka dubokih kolotraga na izvoznome je putu jednostavnije sanirati štetu nego u sastojini. Oni trebaju biti formirani do dobi kad se iz sastojine počinje koristiti drvo, dakle najkasnije do 20. godine. Ipak, zbog svih radova njege šuma koji se rade do tada (popunjavanja, njege pomlatka i mladika te čišćenja) najbolje ih je formirati s prvim uzgojnim zahvatom na plohi poslije dovršnoga sijeka. Nema potrebe raditi npr. popunjavanje sadnicama ili njegu na cijeloj površini, pa u dvadesetoj godini mukotrpno prosijecati izvozne putove i istodobno sjeći biljke koje su sađene tijekom popunjavanja i gdje su napravljeni svi zahvati njega i čišćenja. Formiranjem izvoznih putova u ranoj fazi izbjegava se sav ručni rad na toj površini, koja će kasnije svakako biti izvozni put. Nakon osnivanja potrebno ih je održavati košnjom (Slika 9). S porastom dobi sastojine potreba održavanja izvoznih putova sve je rjeđa, a prestaje kad se mlada sastojina nad njima sklopi. Što se tiče uzgojnih staza, u ranijem poglavlju navedene su i njihove prednosti i njihovi nedostatci. Dugogodišnje iskustvo rada s njima daje nam za pravo tvrditi da njihove prednosti značajno nadvisuju nedostatke koje imaju i preporučiti izradu uzgojnih staza kao u najmanju ruku preporučenu tehnologiju rada u mladim hrastovim sastojinama. Ono o čemu bi svakako trebalo provesti znanstveno-stručno istraživanje i širu raspravu je kolike su optimalne širine izvoznih putova i uzgojnih staza, posebice koliki su njihovi optimalni razmaci, ali i sam njihov položaj tj. usmjerenje. I dok širine staza od 1,5 $\mathrm{m}$ i ne mogu biti značajno manje zbog toga što nema dovoljno jakih i stabilnih traktora koji bi uže gazili od 1,5 m u sastojinskim uvjetima (stari panjevi, kolotrazi itd.), a ni širine putova ne mogu biti manje od $3 \mathrm{~m}$ jer treba omogućiti nesmetan prolazak strojevima kroz sastojinu, dotle razmaci između izvoznih putova i staza mogu biti drugačiji od sadašnjih. Sada u segmentu širine 34,5 m sredina iznosi 17,25 m. Ako se neko stablo nalazi približno u sredini, čak i uz usmjereno obaranje prvi trupac do panja bit će možda i 15ak metara udaljen od agregata na izvoznome putu (ovisno o duljini toga prvoga trupca). Toliki doseg nemaju ni forvarderi ni većina ekipaža, imaju ga samo formet ekipaže opremljene vitlima, ali i njima s povećanjem udaljenosti pada učinak jer je dulje vrijeme i dolaska do trupaca i njihova privitlavanja. Ekipaže koje nisu opremljene vitlima i forvarderi pri razmaku putova od $34,5 \mathrm{~m}$ jedan prohod moraju napraviti kroz sastojinu, pri prolasku oštećujući tlo, žilišta starih stabala i tanka stabla podstojne etaže. Kad bi se, međutim, smanjio razmak između osi prohoda s 37,5 na 25 metara, situacija bi se značajno promijenila. Tada bi segmenti između putova bili široki svega $22 \mathrm{~m}$, sa sredinama od $11 \mathrm{~m}$. To znači da bi, uz usmjereno obaranje, najveća udaljenost do trupaca bila nešto manja od $9 \mathrm{~m}$, što je u pravilu u dosegu forvarder- skih dizalica. U tome bi slučaju broj izvoznih putova u pravilnome nizinskom odjelu dimenzija $750 \times 750$ metara narastao s 19 na 29, a površina bi bila podijeljena na 30 umjesto sadašnjih 20 segmenata. Da ionako velika površina izvoznih putova i uzgojnih staza još više ne naraste, moglo bi se osigurati položajem uzgojnih staza, koje bi se mogle položiti paralelno s putovima. U segmentu širine $22 \mathrm{~m}$ moglo bi se izvući ili dvije staze između putova, koje bi omeđile tri segmenta širine $6,33 \mathrm{~m}$, ili tri staze, koje bi omeđile četiri segmenta širine $4,37 \mathrm{~m}$. Pod uvjetom da u oba slučaja budu samo po dva okomito položena protupožarna puta (na 250 $\mathrm{m}$ i na $500 \mathrm{~m}$ ) širine $3 \mathrm{~m}$, površina putova i staza u prom bi slučaju iznosila svega $24,21 \%$ ukupne površine odjela, a u drugom $30,16 \%$. Dakle, iako bi mreža izvoznih putova bila gušća, čime bi izvoženje drva postalo učinkovitije i jeftinije, a oštećivanje sastojine i tla manje, iskorištavanjem i putova kao uzgojnih staza postiglo bi se u prvom slučaju povećanje obrasle površine odjela za oko $5 \%$ u odnosu na sadašnje stanje, a u drugom slučaju doduše smanjenje za oko $1 \%$, ali tada bi zbog užih segmenata izvršenja na uzgojnim radovima bila veća, tj. postigle bi se uštede. Ipak, treba reći da bi u takvom slučaju u postotku bilo više stabalaca uz rubove staza, koja u početku rastu prema svjetlu i otklanjaju se prema stazi pa trpe i određena oštećenja od mehanizacije. Stoga sugeriramo pokušati s modelom putova razmaka osi od $25 \mathrm{~m}$ s po dvije paralelne staze između. Sve bi ovo trebalo istražiti u terenskome pokusu i pokušati pronaći optimalan broj i raspored ponajprije izvoznih putova, a potom i uzgojnih staza. To treba biti odluka vodstva tvrtke o cjelokupnome načinu rada, odabiru tehnologija i strojeva i strategiji njihove primjene u privlačenju, o čemu zavisi i priprema sastojine mrežom izvoznih putova određenih razmaka.

Iduće pitanje koje smo si postavili u raspravi je kada je najbolje vrijeme za osnivanje mreže izvoznih putova i staza. Jednostavan odgovor na to je da ne treba mijenjati sadašnju praksu: mreža se osniva nakon dovršnoga sijeka u godini kad se radi prvi uzgojni rad, i to prije njegova početka, bilo da je riječ o popunjavanju sadnicama ili o njezi pomlatka. Raniji osnutak bio bi nepotreban trošak, jer bi u godini zahvata već trebala druga košnja stazica, a kasniji osnutak ne bi imao smisla.

Uzgojne staze i putove moguće je izraditi na više načina, a navodi se onaj koji se smatra najboljim. Preduvjet nesmetanoga prolaska traktora po pomladnoj površini nakon dovršnoga sijeka je dobro uspostavljen šumski red, koji podrazumijeva ne samo da je uklonjen drvni materijal s plohe, već $i$ da nema dubokih kolotraga od strojeva nakon izvoženja. Zbog toga izvozne putove u naplodnome i dovršnome sijeku obavezno prije rada treba obilježiti na terenu i nadzirati da ih se vozači forvardera pri radu pridržavaju, što je uostalom i zakonska obveza (Pravilnik o doznaci stabala, obilježavanju drvnih sortimenata, popratnici i šumskom redu, čl. 26.). Ako je tlo dobro nosivo i ne ostanu velika oštećenja tim bo- 
lje, ali ako ostanu duboki kolotrazi treba ih zaravnati (dozerom, bagerom, traktorom s priključkom za zaravnavanje ili ručno, ovisno o opsegu oštećenja i stroju koji je na raspolaganju). Potom treba osnovati izvozne putove i uzgojne staze. Nakon što se GPS tehnologija pokazala potpuno operativno primjenjivom za ovaj posao, svaki drugi način (uz trasiranje) je skuplji, a konačan rezultat jednak. Dakle, svakako se predlaže izrada traktorom s GPS navođenjem. Što se tiče odabira priključka, na raspolaganju je rotositnilica, rotosjekač te prskalica sa stražnjom i bočnim zaštitama. Odabir ovisi o visini, debljini i gustoći svih drvenastih biljaka u trenutku rada. Osnivanje tretmanom kemijskim sredstvima je najjeftinije, ali ako su drvenaste biljke već uzrasle, takva staza nije ugodna za kretanje (Slika 6). Ako je osnivanje moguće napraviti rotosjekačem, što je financijski također povoljno, treba tako napraviti, ali to je vrlo rijetko moguće. Najčešće su uvjeti u sastojini takvi da se osnivanje radi rotositnilicom. Nakon osnutka mreže putova i staza provodi se ručna njega pomlatka. Iduće godine, nakon što drvenasta vegetacija na stazama uzraste, savjetuje se tretiranje staza i putova herbicidom pomoću prskalice sa stražnjom i bočnim zaštitama (Slika 5). To je specijalizirani priključak kojim se tretira samo širina uzgojne staze. Nakon takvoga tretmana stazice ne zarastu još dvije do čak tri godine, a otprilike toliko vremena ne treba raditi ni njegu. Iduće održavanje radi se rotosjekačem u trenutku kad postoji opasnost da se položaji staza više neće vidjeti. Buduća održavanja treba raditi prema stvarnoj potrebi, dakle ili ako prijeti zarastanje do mjere da se položaj neće vidjeti, ili u godini njege neposredno prije samoga zahvata. Ako nema mnogo sporednih drvenastih vrsta pa hrast ne raste brzo u visinu, može se napraviti još jedno održavanje staza kemijski, ako pak pomladak brzo uznapreduje u visinu vjerojatno će primjerenije biti održavanje rotosjekačem. Moraju li se u kasnijim ručnim zahvatima njege zbog visoke i bujne vegetacije sporednih vrsta posječeni dijelovi biljaka odlagati na uzgojne staze, održavanje rotosjekačem treba napraviti tijekom prve naredne godine da se usitne ti, do tada već potpuno isušeni biljni dijelovi i staze privedu funkciji. Ovakva kombinacija strojno-kemijskog održavanja je najjeftinija, a daje dobre rezultate. Alternativa je prvih nekoliko godina svakogodišnja košnja staza rotosjekačem, pa kasnije košnja svake druge godine. Uzgojne staze održavaju se dok za time postoji potreba, a to je najčešće do dobi sastojine od 12-15 godina.

Cijene rada po hektaru, prema Cjeniku Hrvatskih šuma i prosječnim iskustvenim učincima, su sljedeće:

1) Ručna njega vlastitom radnom snagom, cijena rada vlastitih radnika Hrvatskih šuma je 549,22 kn, okvirni utrošak oko $10 \mathrm{RD} / \mathrm{ha}$, što iznosi 5.492,20 kn/ha.

2) Ručna njega vanjskim izvršiteljima putem Agencije za povremeni posao, cijena rada radnika je $267,44 \mathrm{kn}$ dnevno, okvirni utrošak oko $15 \mathrm{RD} / \mathrm{ha}$, što iznosi $4.011,60 \mathrm{kn} / \mathrm{ha}$.
3) Osnivanje uzgojnih staza, rad sitnilicom iznosi $1.742 \mathrm{kn}$ uz utrošak $1,25 \mathrm{SD} / \mathrm{ha}$, što znači da osnivanje staza uz GPS tehnologiju (bez dodatnih troškova pomoćnih radnika) stoji 2.177,50 kn/ha.

4) Održavanje uzgojnih staza uz rad rotosjekačem iznosi $1.276 \mathrm{kn} / \mathrm{ha}$.

5) Osnivanje ili održavanje uzgojnih staza primjenom kemijskih sredstava iznosi $1.237 \mathrm{kn} / \mathrm{ha}$.

Ako postoji potreba za radom njege pomlatka pod zastorom krošanja starih stabala, ta njega se radi bez osnivanja mreže staza i putova, ali najčešće se prvi zahvat radi tek nakon dovršnoga sijeka, u dobi mlade sastojine od 4 ili 5 godina. Potreba održavanja mreže stazica prestaje u dobi oko 15. godine, što znači da obuhvaća prosječno tri zahvata ručne njege (od 4. do 15. godine dobi sastojine). Kad bi se radila samo njega pomlatka i mladika ručno, bez staza i izvoznih putova, cijena triju zahvata uz utrošak 10 radnikodana po hektaru i rad vlastitih radnika bila bi 5.492,20 $\times 3$ $=16.476,60 \mathrm{kn} / \mathrm{ha}$. Ako bi se za isti rad uvijek koristile usluge Agencije za povremeni posao (čiji radnici su jeftiniji, ali postižu u prosjeku slabije učinke) cijena bi bila 4.011,60 $\times 3=12.034,80 \mathrm{kn} / \mathrm{ha}$. Radi li se klasično osnivanje staza sitnilicom pa održavanje rotosjekačem, u tih 12 godina treba računati na 7 košnji (osnivanje i šest održavanja, prve tri godine svakako, a dalje okvirno svake druge godine, $s$ tim da se obavezno provodi u godini rada ručne njege). Cijena toga rada je 2.177,50 +6 $\times 1.276=9.833,50 \mathrm{kn} / \mathrm{ha}$. Ako se osnivanje staza radi primjenom kemijskih sredstava i barem još jedno kasnije održavanje također, onda je dovoljno raditi šest puta pa je cijena još niža i iznosi $2 \times 1.237+4 \times$ $1.276=7.578,00 \mathrm{kn} / \mathrm{ha}$. Iako cijena ručnih zahvata može biti niža (lakši uvjeti i bolja izvršenja), ona može biti i znatno viša ( $r a d$ u težim uvjetima s utroškom od 15 i više radniko dana po hektaru). Imajući sve navedeno u vidu, jasno je da osnivanje i održavanje mreže uzgojnih staza ne poskupljuje radove njege sastojina već ih čini jeftinijima.

\section{ZAKLJUČCI}

\section{CONCLUSIONS}

Tehnologija izrade i održavanja uzgojnih staza u šumama kojima gospodari Trgovačko društvo Hrvatske šume d.o.o. postoji već dugi niz godina. $U$ pojedinim organizacijskim jedinicama tvrtke (Upravama šuma podružnicama) ova se tehnologija koristi, dok u drugima ne. Ondje gdje se koristi primjenjuju se različiti razmaci uzgojnih staza i izvoznih putova. Prednost ne izrađivanja staza ogleda se u jednolikome i pravilnijemu rastu i razvoju hrastovih stabalaca na plohi, očuvanju svih poniklih stabala u početku te zadržavanju potpuno prirodnoga izgleda takvih pomladaka i mladika. S druge strane, rad njege po površini bez staza naporniji je radnicima, teže im je kretanje, slabija preglednost, veća mogućnost ozljede, a posječeni materijal u njegama često 
pritisne i savije hrastove biljke. Na dijelovima površine pod amorfom, kupinom i sl. hrastove biljke između dvaju zahvata njege nerijetko propadnu. Obračun učinka u slučaju rada bez staza najčešće se mora raditi za cijelu skupinu radnika, čime se izjednače oni koji bolje i lošije rade, što djeluje demotivirajuće na najbolje radnike. Kontrola kvalitete rada i učinka vrlo je teška zbog slabe prohodnosti po odnjegovanome dijelu površine, a sam rad je skuplji. Zbog svega toga napravljeni su pokusi osnivanja uzgojnih staza još krajem sedamdesetih godina prošloga stoljeća, i to $s$ međusobnim razmacima od 30, 10 i 5 metara (Sabljak 1990). Zaključeno je da od ta tri slučaja pozitivni učinci uzgojnih staza dolaze do izražaja tek pri razmaku staza od $5 \mathrm{~m}$ i ta je tehnologija preporučena za primjenu u tadašnjoj Složenoj šumsko-gospodarskoj organizaciji „Slavonska šuma“. Pri izradi staza svi navedeni nedostatci rada njege po površini bivaju otklonjeni ili umanjeni. Zbog toga, prema dosadašnjemu iskustvu, možemo reći da prednosti osnivanja uzgojnih staza nadmašuju nedostatke. Formiranje mreže izvoznih putova treba napraviti istodobno s izradom uzgojnih staza. Tu svakako savjetujemo, uz postojeću mrežu putova međusobnih udaljenosti $34,5 \mathrm{~m}$ i na njih okomitih staza međusobnih razmaka $5 \mathrm{~m}$, pokušati pokusno položiti mrežu putova međusobno udaljenih $22 \mathrm{~m}$ s po dvije paralelno položene staze između njih međusobnih udaljenosti $6,33 \mathrm{~m}$. Time bi udio obrasle površine odjela narastao sa sadašnjih $71 \%$ na $76 \%$, a putove bi se do 20. godine starosti sastojine rabilo kao uzgojne staze. U svrhu pokusa na manjim bi površinama trebalo istražiti prednosti i nedostatke i gušće mreže putova, kao i različitih položaja i razmaka uzgojnih staza. Mreža putova razmaka osi od $25 \mathrm{~m}$ pri kasnijemu gospodarenju sastojinama olakšala bi radove doznake i sječe, a posebice izvoženja drva. Svuda bi mogli raditi forvarderi bez napuštanja izvoznih putova, čime bi se izbjegla vožnja kroz sastojinu pri kojoj nastaju najveća oštećenja dubećih stabala, smanjila bi se površina gaženja, a vjerojatno bi se i učinci povećali. Formet ekipaže opremljene vitlima, koje mogu raditi bez napuštanja putova i pri njihovim većim razmacima, u slučaju međusobnoga razmaka putova od $22 \mathrm{~m}$ sigurno bi postizale veće učinke nego pri $34,5 \mathrm{~m}$. Na područjima pridolaska hrasta lužnjaka gdje odjeli nisu pravilni treba formirati najpogodniju mrežu putova i uzgojnih staza, s tim da međusobni razmak putova nikako ne bi trebao biti veći od $40 \mathrm{~m}$, a uzgojnih staza od $7 \mathrm{~m}$, jer se $\mathrm{s}$ njegovim povećanjem gubi većina pozitivnih učinaka. Sve navedeno svjedoči da je tehnologija vrijedna sustavnoga proučavanja i istraživanja učinkovitosti radova njege u prvih 20 godina života hrastove sastojine, ostvarenih troškova i utjecaja izrade mreže uzgojnih staza na rast i razvoj stabala u sastojini. Također treba istražiti koji je optimalni razmak izvoznih putova, uzimajući pritom u obzir štete na tlu i sastojini, troškove privlačenja i ostale relevantne parametre. Kad se provedu takva istraživanja, na temelju njih Hrvatske bi šume trebale donijeti obvezujuću tehnologiju rada, ili barem onu preporučenu.

\section{LITERATURA}

\section{REFERENCES}

- Allman, M., Ferenčík, M., Jankovský, M., Stanovský, M., Messingerová, V., 2015: Damage Caused by Wheeled Skidders on Cambisols of Central Europe. Croat. j. for. eng. 36(2): 205-215

- Borchert, H., Huber, C., Göttlein, A., Kremer, J., 2015: Nutrient Concentration on Skid Trails under Brush-Mats - Is a Redistribution of Nutrients Possible? Croat. j. for. eng. 36(2): 243-252.

- Cambi, M., Grigolato, S., Neri, F., Picchio, R., Marchi, E., 2016: Effects of Forwarder Operation on Soil Physical Characteristics: a Case Study in the Italian Alps. Croat. j. for. eng. 37(2): 233239.

- Cudzik, A., Brennensthul, M., Białczyk, W., Czarnecki, J., 2017: Damage to Soil and Residual Trees Caused by Different Logging Systems Applied to Late Thinning. Croat. j. for. eng. 38(1): 8395.

- Greulich, F. R., Hanley, D. P., McNeel, J. F., Baumgartner, D., 2004: A Primer for Timber Harvesting. Cooperative Extension - College of Agriculture and Home Economics, Washington State University Pullman, Washington, 1 - 33.

- Labelle, E.R., Jaeger, D., Poltorak, B.J., 2015: Assessing the Ability of Hardwood and Softwood Brush Mats to Distribute Applied Loads. Croat. j. for. eng. 36(2): 227-242.

- Pandur, Z., Poršinsky, T., Šušnjar, M., Zorić, M., Vusić, D., 2014: Gaženje tla pri izvoženju drva forvarderom u sječinama hrasta lužnjaka. Nova meh. šumar. 35: 23-34.

- Poršinsky, T., 2005: Djelotvornost i ekološka pogodnost forvardera Timberjack 1710 pri izvoženju oblovine iz nizinskih šuma Hrvatske, disertacija, Sveučilište u Zagrebu, Šumarski fakultet

- Poršinsky, T., Stankić, I., Bosner, A., 2011: Ecoefficient Timber Forwarding Based on Nominal Ground Pressure Analysis. Croat. j. for. eng. 31(1): 345-356.

- Posarić, D., 2007: Vodič za revirničke poslove s primjerima iz spačvanskih nizinskih šuma, 232 str., Hrvatske šume d.o.o., Zagreb

- Pravilnik o doznaci stabala, obilježavanju drvnih sortimenata, popratnici i šumskom redu, NN 17/2015, 57/2017

- Sabljak, S., 1990: Prilog za uvođenje novih metoda na njezi podmlatka hrasta lužnjaka, Šumarski list 5-6, Zagreb

- Slabak, M., 1983: Forvarderi u svijetu i kod nas. Zbornik radova „Mehanizacija šumarstva u teoriji i praksi“, Opatija, 351 - 361.

- Solgi, A., Naghdi, R., Tsioras, P.A., Nikooy, M., 2015: Soil Compaction and Porosity Changes Caused During the Operation of Timberjack 450C Skidder in Northern Iran. Croat. j. for. eng. 36(2): 217-225.

- Solgi, A., Naghdi, R., Tsioras, P.A., Ilstedt, U., Salehi, A., Nikooy, M., 2017: Combined Effects of Skidding Direction, Skid Trail Slope and Traffic Frequency on Soil Disturbance in North Mountainous Forest of Iran. Croat. j. for. eng. 38(1): 97-106.

- Stankić, I., 2010.: Višekriterijsko planiranje izvoženja drva forvarderima iz nizinskih šuma Hrvatske, (Multicriterial planning of timber forwarding in Croatian lowland forests), Disertacija, Sveučilište u Zagrebu Šumarski fakultet, str. 1-123.

- Tonković, D., 1983: Organiziranost šumarstva Slavonije od prvih početaka do danas Šumarski list 9-10, Zagreb 


\section{SUMMARY}

The establishment of silvicultural trails in young pedunculate oak forests for the purpose of simplifying work of tending young stands and more effective control of done work in Croatia was first made in 1977 in forest area managed by Forest Office Đurđenovac (Sabljak 1990) and Forest Office Cerna. Since then, it has gradually expanded as an accepted technology of work mainly in the Slavonian Forest Administrations of the Croatian Forests ltd., while in other Forest Administrations it was not accepted. Croatian Forests ltd. still have not analyzed the effectiveness of this technology, and the decision of its implementation has been left to the Forest Administrations, even Forest Offices. The technology is based on the formation of a $3 \mathrm{~m}$ wide regular network of haulage tracks perpendicular to the forest road and silvicultural trails $1.5 \mathrm{~m}$ wide parallel to the same forest road. The production area between the trails is different in width in different Forest Administrations, but most often $5 \mathrm{~m}$. The grid is formed in the year of the first intervention after the final cut (before filling with seedlings or tending). It is easier to work when trails exist, and the control of a done work is especially effective. On the other hand, it is cut down between 24 and $29 \%$ of already rejuvenated surfaces, which is the basic argument for the opponents of this technology. The article proposes to try different ways and positions of silvicultural trails. Haulage tracks are made simultaneously with the silvicultural trails and are used to haul wood material from the beginning of the thinning process to the end of the rotation period. The haulage tracks axis distance in the $750 \times 750 \mathrm{~m}$ dimension forest compartments is $37.5 \mathrm{~m}$, which divides the compartment's surface into 20 equal segments. In compartments with other dimensions the spacing varies usually between 40 and $50 \mathrm{~m}$, and the increasing of spacing between the haulage tracks reduces the efficiency of hauling. Therefore, it would be worthwhile testing the different distances between the axis of the haulage tracks, in the first place that one of 25 meters. Since this issue has very little written material in our country, and technology has been in use for many years, this article aims to describe the present situation, to indicate the good and bad sides of the establishment of haulage tracks and silvicultural trails grid, and to initiate a discussion with the ultimate goal of defining the optimal way of work and especially its unification and application throughout the pedunculate oak area in Croatia.

KEY WORDS: Pedunculate oak, tending of stands, silvicultural trails, haulage tracks, haul. 